\title{
Marketing Mix in Tourism
}

\section{Dr Elida Ciriković}

elida.cirikovic@unhz.eu

\section{Doi:10.5901/ajis.2014.v3n2p111}

\section{Abstract}

In terms of globalization, turbulent and highly complex environment, competition is stronger and more ruthless. Tourism companies are faced with the need to find new ways, paths and methods for achieving sustainable competitive advantage. Tourism market is determined primarily by tourism demand and tourism offers. Tourism demand is determined by the motives as the driving force behind every deliberated planed activity, the family as the basic cell of society which is in charge of tourism demand, the image if it represents potential destinations, lifestyle of tourism services potential consumers, which is connected to a life cycle of an individual or a family. Tourism offer represents a temporal and spatial synchronization of attractive, communicative and receptive factors. An important feature of the tourism offer is its inflexibility, precisely due to the immutability of its basic offer elements. In the realization of market needs of Tourism Company, the key role belongs to marketing, which through its activities, primarily through marketing mix should identify and differentiate tourism product (compared to competition) and thus implement its strategic objectives. Marketing in the tourism has its own characteristics that derive from the fact that the product in tourism is a service. Besides, the invisibility of a product gives even more importance to the marketing. With the help of the marketing mix elements: product, price, promotion and distribution, the tourism organization adapts to environmental conditions, thus realizing its mission. This paper shows the importance of marketing and marketing mix elements separately (product, price, promotion and distribution) in the economic activities of tourism organizations.

Keywords: Marketing, tourists, markets and market structure, destination, product, price, promotion, distribution.

\section{Introduction}

Tourism is often defined as the provision of services to people who are traveling and staying outside their usual residence for a period shorter than one year, during holidays or for business purposes. Under the marketing of tourism we include all the marketing activities of producers who are in any way connected to the sale of their products in the tourism market. The reasons for studying marketing in tourism are reflected in the specifics of the tourism market, tourism products and tourism consumer. Unković(1998.) defines it as "a diverse business activity, which includes a variety of commercial and noncommercial actions, which all work together in meeting the needs of domestic and foreign tourists"(pg.23). If we start from the observation that the tourism is an economic activity of a dynamic category, and as such, seeking retention and attracting new consumers of tourism services, this activity tends to new types of organizations, new resources, improving existing ones, combining them in new forms of the Strategy, offering arrangements which are constantly being updated and enriched. At what intensity and in which direction the tourism will develop depends primarily on demographic characteristics, specifically the size and the structure of population, economic resources, and political and cultural movements. The tourism sector as a whole is one of the fastest growing economic sectors in Europe and in the world. In previous years, the rate of growth in the tourism sector was higher than the average growth rate of the world economy. The factors that mainly influence the development of tourism are:limitations of market growth;destinations and diversification; modification of tourism distribution; socially responsible marketing;changes in political structure;Clearly, one can draw the conclusion that the marketing is a factor that has a decisive importance for the development of tourism. Therefore, the aim of this paper work is to highlight the importance of marketing, particularly marketing mix in tourism development.

\section{Marketing in Tourism}

One of the areas where the marketing found wide application is tourism, which can still be called a "traveling industry." The aim of marketing in tourism is the production and placement of products to suit a wider range of tourism consumers. It should facilitate the exchange process on the tourism trade. Marketing in tourism can be seen as the subsystem in the system of marketing services. And by services, we mean all those activities, as the final product does not have a physical 
product, but is a product that is consumed at the time of its production, which leads to the creation of added value, which is invisible and intangible for the consumer(Zeithaml \& Bitner,2003.). The tourism product is a complex product, because it consists of goods and services in different activities. Today, the tourism product is usually a combination of accommodation offer, food, animation. Based on the aforementioned, it can be said that the aim of marketing in tourism is information gathering and analysis, based on which the tourism offer is built as an integrated tourism product to permanently communicate with customers in order to inform them about the current and future offers. All these activities are an integral part of the marketing policy, aimed at defining measures and strategies for achieving those objectives. Marketing in tourism has its own specificity, which arises from the fact that the tourism product is a service. Such a defined tourism product is offered in the trade of tourism.

\subsection{Tourism market}

What characterizes other commodity markets, characterizes also the tourism market, which is reflected in its existing four main constituent elements: offer, demand, demand object and price. Tourism market is a set of relations of demand and offer that are focused on the exchange of goods and services by means of money and with the extent determined by the prices of goods and services(MarkovićS.\&Z.,1972.). Given this definition, the tourism demand is a matter of all persons who travel or want to travel outside of place where they live, and in that respect they use the tourism facilities. In order to exist, there must be a desire to travel, payment capacity and willingness to buy such a service. Detection of tourism demand is conditioned by the existence of free time and free money resources. What will be the tourist demand will depend on many different factors, which can be classified into three major groups: economic, demographic and environmental factors (so called exogenous factors).All these factors, in its way condition some characteristics of tourism demand. It is primarily elastic; sensitive to price services, heterogeneous (which expresses the strategy of differentiated and concentrated marketing). Considering that the tourist offer is mobile, the demand in this market is focused on offering, which is one of the characteristic that makes the difference from the touristic demand in other markets.Seasonal concentration of tourism offer should have a special attention, because this feature is imposing special caution in defining business objectives and their implementation, planning capacity, services and seasonal workforce. Tourism demand determines the motives as the driving force behind every deliberated planned activity, the family as the basic cell of society that is also a bearer of tourism demand, image, as a notion of potential destination, lifestyle of potential consumers' tourism services, which is connected to the life cycle of an individual or a family. Tourism offer represents temporal and spatial synchronization of attractive, communicative and receptive factors (Bakić,2010.). The thing that characterizes the tourist offer (and demand) is a high degree of heterogeneity in terms of a number of alternatives and options. An important feature of the tourism offer is its inflexibility, precisely because of the immutability of its fundamental offer elements. In order to have a less rigid tourism offer, the solution can be found in the sale of tourist packages in advance (so called package arrangements), which are favorable to both, the tourism industry, and tourists..This method reduces the gap (GAP), which can occur between the tourism offer and demand. The key role in the process of tying the tourism offer and demand are touristic agencies. As in all other economic activities, marketing in tourism is primarily applied through the application of marketing mix concept, known as $4 \mathrm{P}$.

\subsection{Marketing mix in tourism}

Key role in achieving the competitive position of the company and the tourism belongs to marketing, as a key feature of any economic activity. It, through operational performance achieves the most optimal combination of marketing mix. The chosen marketing strategy varies through a specific elements' combination of the marketing mix. The goal is to meet more efficiently the needs of consumers in that market segment in which it is directed. This success is largely dependent on the organizational and financial resources which specific tourism organization has, which in tourism industry consists of four elements: product, price, distribution and promotion. Based on these elements, the tourism organization in the best possible way adapts to the demands of the tourism market. To what extent is the combination chosen, in tourism, 4 elements mix, will be best seen in repeated purchases by consumers, namely in its loyalty. By this, the clear importance is relationship: the quality-satisfaction-loyalty.

\subsubsection{Tourism product}

The tourism product is a complex set of different physical resources, activities and services. By buying this combination of 
natural resources, activities and services, the guest buys a desire for experience, for certain experience. It can be freely said that it is leading, carrying instrument in the business and tourism industry. It can be defined as the sum of various details, goods and services, which serve to satisfy the travel needs of customers out of their travel places and residence in resting places(Kobašić,1977.). If there are generally five levels of products: product at substantial utility, a generic product, expected product, enriched product and potential product(Tihi ed al.,1999.), from the standpoint of marketing in tourism it can be distinguished:

$>$ The main product - the main goal of marketing is in discovering the basic utility that consumers expect from the product, based on that the accent should be placed on features.

$>$ Expected product - includes goods and services that must be present in order for underlying product to be used by guest, and it depends on the target market and present expectations.

$>$ Additional product - what makes a product different from the competition's product is an additional product that enriches the core product.

> Expanded product (Kotler,Bowen\&Makens,2010.) - Expanded product consists of circumstances for offering a service to the customer. These circumstances are the atmosphere, the interaction of a customer with the serving system, customer participation in the production and mutual interaction of clients. The atmosphere itself is a contributing factor in the marketing product offer of tourism, because it attracts the attention of potential customers by sending message and influencing their behavior.

What will be the quality of the tourism product; will depend on the imaginary and creative human work as well as the direct contact between guests and the direct executors. Under the tourism product is considered a tourism destination, and by this it is meant a place or series of places that tourists visit, where they can stay, which is also the main goal of their visit(Holloway,1983.). In this case, the characteristics of such a defined product are:

$>$ Destination attractiveness - it makes a whole range of natural and social characteristics to a destination;

$>$ Destination accessibility - it refers to the distance expressed through travel costs and not the literal geographical distance between a fixed place of tourists and tourist destinations. Certainly, the competitiveness of bidders tourist offer is much better if a tourism destination is closer to the domicile of tourists.

$>$ The condition to stay on site - includes a set of additional assumptions whose presence and quality conditions a stay quality in a tourism destination.

Such a defined product is the basis for defining the price.

\subsubsection{Price of tourism products}

When we talk about the price, as the element of marketing mix, it should be emphasized that only it, unlike the other elements that imply costs, generates income. Pricing of tourism products (and indeed every other) is a very sensitive job. Under the conditions of intense competition, higher prices could cause a decline in sales and thus influence the total income. On the other hand, the price has to cover production costs and ensure a profit. What will be the price for a particular product will depend primarily on the objectives to be achieved by a defined price?

Due to changes and increased competition, changes in the requirements and tastes of tourists, extensive unused capacities, tourism companies can define and establish rates that will primarily allow surviving in such adverse conditions.If Tourism Company is disposing with modest business capabilities, it can define goals that will ensure maximizing of short-term profits. In this way, it will define prices that will ensure the highest possible profit, and in view of the current constellation of favorable demand. Low initial cost can be defined by the tourism companies seeking to secure high market participation. This is especially valid when the company is entering in a new geographic market, aiming at high market positioning based on participation. In this instance, the so called penetration rate comes to expression. When a tourist company places in the first line the high quality product, then such a quality of its tourism product is defined with a very high price, which for this specific reason is called "price which removes the cream."These prices will cover the high cost of production of such a quality product; on the other hand it is based on the assumption that a high price creates a costumer's perception on a high quality product. One thing is certain. Product price has to cover the costs of production, which represents the lower limit of its definition. What will the ceiling price be, it all depends on the market itself..A market that is expanding will condition the creation of prices at a higher level, while the opposite situation will be in a market that is in a stagnant position. When it comes to prices, including the prices of tourism products, it should be mentioned as an unavoidable problem and the phenomenon of price elasticity demand, which typically moves opposite to price changes. What kind of degree the price elasticity will cause, will depend, among other things, on the consumer's perception towards the product value, as well as the existence of substitute for the given product. When it comes to pricing, it should 
be noted that it is influenced by a number of economic, credit, monetary and fiscal policies' factors of the state. Based on aforementioned, it can be said that the price is a factor of resource allocation and positioning of a given tourism organization.

\subsubsection{Promotion in tourism}

Promotion as a marketing mix element is intended to provide support for the placement of product in the tourism market and to create awareness about it, create the image, and finally and most importantly to conduct it's positioning in the market. In a word, the goal of the promotional mix is to provide a favorable image of the tourism product to potential tourists and thus enable it to be their first choice. Given the aforementioned, it can be said that the aim of promoting tourism is to:

$>$ Create a positive image, the image of tourism organization and destination, thereby improving the position in tourist market.

$>$ Give the right information at the right time in the purchase of travel services.

$>$ Provide assistance to distributors in creating acceptable offer for less integrated tourist destinations (products).

In a word, the goal of the promotion is to incite preference for one or more services of the tourist organization, destination, which is achieved by transmitting a clearly defined, consistent message. It is of crucial importance to determine the specific instrument of a defined promotional activity, budgets and media (and within it the vehicle). There are many instruments of promotional mix, but the most important are: economic propaganda, public relations, sales promotion, personal selling, publicity and direct marketing. If we define the economic propaganda as any form of promotional activity, as well as its effect of rapid capture of a wide audience, a large number of repetitions, then its importance is clear in the overall promotional activities of tourism organizations. Its resources are press, radio, television, direct mail. The concept of the public in the process of value creation for the touristic offer is extremely important, which also highlights the promotional instrument, public relations that have a long-term interests for a given tourist organization.Fostering public relations contributes to strengthening and improving the image of specific tourism organizations, and thus indirectly influences its favorable positioning in the perception of potential tourists. Sales promotion encourages more buying, and is therefore focused on immediate results. Hence, the long term goals should be taken into account and should not be compromised. This instrument of promotional activities focuses its work on segments, distribution channels and personal sales staff. Personal selling as a mean of promotion enables direct face to face contact with potential tourists, which allows direct interaction between the seller and the customer of travel services. In this way, a seller is able to establish concrete and specific needs of the customer and based on that implement a sales presentation. With such a defined communication, a seller is able to solve the specific problem that a customer may have. It is particularly suitable when the tourism activity is involved and for hotel organizations operating in the chain. Publicity can be seen as an integral part of public relations. It implies placing of

commercial news or news through the mass media that the company does not pay(Tihi et al.,1999.). Then, the ascertainment is clear that the publicity success depends on good relations with the media. As a new method of direct communication with consumers, direct marketing involves distribution of products, information and promotional benefits to target customers through interactive communication, in a manner that allows gauging their reaction(Jobber\&Fahy,2006.). It is characterized by a high degree of precision in targeting, acquiring direct and rapid response by the customer, but also easy and fast measuring of marketing activity effects.

\subsubsection{Distribution in tourism}

If it is known that the task of distribution is to connect the producer and the consumer, still the difference should be made between the distributions in production process, as it aims to put the product availability to the consumer, therefore in tourism the task of distribution is to bring the customer to the service system. The importance, which the distribution has for tourism Service Company and for the consumer is exactly the reduction of transactions and communication channels, which facilitates the entire product availability process. Considering that it performs a specialized activity, the cost distribution will be much smaller than if the tourism companies would itself organize such a process. There is an entire range of travel mediators, which perform the function of distribution. Kotler states that they are: travel agents, tour wholesalers, specialist, hotel representatives, national, federal and local travel agencies, consortia and reservation systems, Internet, receptionists(Kotler,Bowen\&Makens,2010.). Given that travel agents charge a commission for their services, it increases the tourism product final price cost, a drop in demand for this type of mediator appears as a 
tendency in the world. Their dwindling popularity is caused by the Internet, enabling direct communication of a bidder and the user of tourism services. Tour wholesalers create travel packages offered to tourism trade. A tourism travel package usually includes transportation, accommodation, meals and entertainment expenses. Operations of tour-operators are primarily travel arrangements, and that means organization, sale and execution of travel arrangements.

When wholesalers do business through travel agents there is little room left for profit. Specialists, as their name implies, are engaged in the distribution of those services for which they are specialized, having thus efficient distribution. The hotel representatives for selling hotel services is typically used by hotels for remote and unknown destinations Nations, federal and local tourism agencies are promoting tourism, each within their geographic destination. The Consortium consists of a group of hotel organization, which is formed for mutual benefit of members. It allows to its member the autonomy in the ownership and to the management the advantage to use the group marketing. Booking system provides booking services, calling a local number in order to contact the hotel. The main characteristics of the Internet, besides taking over operations of travel agencies, it is a distribution channel available 24 hours a day and has a global coverage with the sound and picture. If you add to it that it is simple to use and to reduce the cost of human labor, it is clear why it is a very convenient distribution channel. Receptionists could somehow be included in the distribution channels, because they are in direct contact with tourists, so they act as promoters in this sense that will direct tourists to the particular service facilities. The thing which can cause a change in tourism distribution is also the demand individualization trend. E - Commerce leads to a different approach the potential customers having thus each tourist consumer become a market for itself.

\section{Conclusion}

The implementation of planned and defined goals, whether it is a tourist destination or tourism bidder offer, is achieved by combining the elements of the marketing mix. Specified elements of the marketing mix have a very complex content which is relevant to both business and tourism policy. Leading, carrying element in this mixture is certainly the tourism product, which, considering that it is related to a service it is very specific and demanding. It is essential to define and emphasize those elements of the product, which should lead to a desired reaction of consumers in the tourism market. Such a defined product must be determined with the appropriate price. In the process of its defining the relationship of supply and demand must be taken into account, the lower and upper bound rates, as well as the quality of tourist product and its price. Task of the promotional mix is to ensure recognition of a concrete tourism product and its positioning in the tourism market. Based on the characteristics of tourism product, the need for creativity and innovation in addressing potential tourists is of particular importance. How will the tourist product reach its consumers, with a defined price and propaganda work carried out, will depend on the selected mode and distribution channels, which should be a symbiosis and final step in offering tourism products with defined elements of the marketing mix. The key to success is finding the optimal combination of these elements. It implies such a marketing decision that optimally allocates production resources in order to realize a consistent and complementary combination of marketing mix elements. This objective can be achieved on the basis of functional and overall alignment between the organization orientation (and thus tourism) towards achieving the maximum business results on one hand, and the needs of consumers on the other.

\section{References}

Bakić O., Marketing u turizmu,Univerzitet Singidunum,Beograd,2010.

Christopher Holloway J., The Business of Turism,McDonald and Evens,London,1983.

Grupa autora,redaktor Tihi B.,Osnovi marketinga,Ekonomski Fakultet Sarajevo,Sarajevo,1999.

Jobber D.,Fahy J.,Osnovi marketinga,Data status,Beograd,2006.

Kobašić A.,Marketing u turizmu,Fakultet za turizam i vanjsku trgovinu,Dubrovnik,1977.

Kotler, P., Bowen, J.T., Makens, J.C.,Marketing u ugostiteljstvu, hotelijerstvu i turizmu, MATE, Zagreb, 2010.

Marković S. i Z. Ekonomika turizma,Školska knjiga,Zagreb,1972.

Unković S.,Ekonomika turizma,Savremena administracija,Beograd,1998.

Valerie A. Zeithaml,Mery J.Bitner, Service Marketing,McGravv-Hill,Irvin,New York,2003. 
